\begin{tabular}{|c|c|c|}
\hline 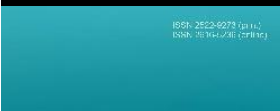 & & $\begin{array}{l}\text { ISSN 2522-9273 (print) } \\
\text { ISSN 2616-5236 (online) }\end{array}$ \\
\hline & & $\begin{array}{l}\text { Economies' Horizons, No. } \\
\text { 1(8), pp. 107-112. }\end{array}$ \\
\hline 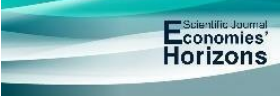 & Homepage: http://eh.udpu.edu.ua & DOI: $\frac{\text { https://doi.org/10.31499/2616- }}{5236.1(8) .2019 .228690}$ \\
\hline
\end{tabular}

UDC 338

\title{
Marketing of a healthy lifestyle as an object of the sports industry
}

\section{Yaroslav Leonov ${ }^{1}$, Cand. Ec. Sc., Associate Professor}

Abstract. The purpose of the research. There are studies of problematic aspects of marketing support in the formation of a healthy lifestyle of the population. Methodology. In the process of writing article, various general scientific and specific methods of research, in particular induction and deductions, historical, logical and comparison system, observation, generalization and comparison in the stage of generalization of theoretical provisions and formation of conclusions from this study were used. Results. The article deals with the role of the organizations of the sports industry in the formation of a healthy lifestyle and physical activity of the population. The sports industry in recent years becomes an integral part of everyday life of people, increases the number of organizations - sports product manufacturers (sports clubs, fitness centers, gym, swimming pools, etc.), increases the number of sports, sports goods sellers, inventory., equipment, growing number and quality of media. In the conditions of globalization of economic relations, freedom of movement of people and information exchange, the number of sports fans present in competitions are constantly increasing, or which are watching television, listen to radio broadcasts and use the Internet. However, the lack of funds for supporting and developing sports infrastructure, ensuring the training of athletes, conducting competitions are a serious problem in front of the organizations of the sports industry of non-commercial type. It is determined that under the influence of socio-economic processes occurring in society, queries, needs and demands of people on the quality of products (goods, services) are changing. At the same time, the role of marketing management as a component of sports organizations (federations, sports clubs, sports schools, etc.) increases. The issue of internal organizational changes, methodological and information support. The importance of physical activity has been investigated in human life.

Keywords: direct tax; curve; surface; effect; maximization; optimization; government tax revenue.

${ }^{1}$ Kharkiv State Academy of Physical Culture, Associate Professor at the Department of Physical Culture Management ORCID: https://orcid.org/0000-0001-8837-5744 E-mail: leonov.yaroslav.2017@gmail.com 
Number of references: 6; number of tables: 0; number of figures:0; number of formulas: 0.

\section{Маркетинг здорового життя як об'єкт спортивної індустрії}

\section{Я. В. Леонов ${ }^{1}$, к. е. н., доцент}

Анотація. Метою статті є дослідження проблемних аспектів маркетингового забезпечення при формуванні здорового способу життя населення. Методологія. В процесі написання статті застосовувалися різні загальнонаукові та специфічні методи дослідження, зокрема, індукції i дедукції, історичний, логічний i порівняння, системний, спостереження, узагальнення та порівняння на етапі узагальнення теоретичних положень і формуванні висновків з даного дослідження. Результати. У статті розглянуто роль організацій спортивної індустрії у формуванні здорового способу життя та фізичної активності населення. Спортивна індустрія в останні роки стає невід'ємною частиною повсякденного життя людей, зростає кількість організацій - виробників спортивного продукту (спортивні клуби, фітнес центри, тренажерні зали, басейни та ін.), збільшується кількість людей, що займаються спортом, продавців спортивних товарів, інвентарю, обладнання, росте кількість та якість засобів масової інформації. В умовах глобалізації економічних відносин, свободи пересування людей й обміну інформацією, постійно збільшується число спортивних уболівальників, присутніх на змаганнях особисто, або які спостерігають по телебаченню, слухають радіотрансляції та використовують інтернет. Однак, відсутність коштів для підтримки та розвитку спортивної інфраструктури, забезпечення підготовки спортсменів, проведення змагань $є$ серйозною проблемою перед організаціями спортивної індустрії некомерційного типу. Визначено, що під впливом соціально-економічних процесів, що відбуваються у суспільстві, змінюються запити, потреби та вимоги людей щодо якості продуктів (товарів, послуг). Водночас посилюється роль маркетингового управління як складової діяльності спортивних організацій (федерацій, спортивних клубів, спортивних шкіл та ін.).

Ключові слова: спортивна індустрія; організації спортивної індустрії; органи державного управління; здоровий спосіб життя; фізична активність; маркетинг; людський капітал.

Кількість джерел: 6; кількість таблищь:0; кількість рисунків: 0; кількість формул: 0.

\section{Introduction.}

The formation of the post-industrial economy has affected not only the gradual transformation of society from the economy based on the production of goods, to the economy based on the production and application of knowledge. The main thing is that an extraordinary value acquires a mental work of a person; technologies create global competition; innovations become more important than

\footnotetext{
${ }^{1}$ Харківська державна академія фізичної культури, доцент кафедри менеджменту фізичної культури ORCID: https://orcid.org/0000-0001-8837-5744 E-mail: leonov.yaroslav.2017@gmail.com
} 
mass production; Investments are faster invested in new ideas than new equipment. Decisive importance for the knowledge economy acquires human capital.

Under the influence of innovative processes taking place in society, requests, needs and demands of people regarding the quality of products (goods, services) are changing. At the same time, the role of marketing support, as an integral part of sports organizations (federations, sports clubs, sports schools, etc.). The issue of internal organizational changes, methodological and information support. Recently, in Ukraine, as in other countries, there is an adaptation of the organizations of the sports industry to a market environment, which objectively leads to new processes and phenomena: There are significant changes in the system of socioeconomic relations, new forms of ownership and form of management are emerging. These processes affect the behavior of all market participants: suppliers of sports goods, equipment, etc.; manufacturers of sports product (sports and recreation services, sports events, etc.); the sports product users. Issues of health and healthy lifestyles are more relevant, especially among young people, which falls under the negative seal of society, friends, colleagues. In the life of modern society, problems associated with tobacco, drug addiction and alcohol are acute.

Formation of a healthy lifestyle Marketing means - a set of interconnected and consistent actions by the organizations of the sports industry, which make up the theoretical and practical base in the context of the formation of market relations that allow us to explore the requests, needs of people in order to meet them, the production of a qualitative sports product and raising the level of health of the population.

\section{Literature review.}

Generalization of the achievements of modern management and economic thought from theoretical and methodological issues of an innovative approach to the formation of a healthy lifestyle are revealed in the works of $\mathrm{W}$, Andreff and Stefan Szymanski (2006), etc. Global studies of theory and practice are carried out by international consulting agencies and WHO. However, there are unresolved problems of marketing support for the formation of a healthy lifestyle and physical activity of the population.

\section{Methods.}

During the study, basic general scientific and special research methods are used: induction, deduction, historical, logical, comparison, system, observation, generalization.

\section{Research objectives.}

Justification of marketing provision in the formation of a healthy lifestyle of the population.

\section{Results and discussions.}

The sports industry in recent years becomes an integral part of everyday life of people, increases the number of organizations - sports product manufacturers (sports clubs, fitness centers, gym, swimming pools, etc.), increases the number of sports, sports goods sellers, inventory, equipment, growing number and quality of media. In the context of globalization of economic relations, freedom of movement of people and information exchange, the number of sports fans present in competitions are constantly increasing, or who are watching television, listen to radio broadcasts and use the Internet. However, the lack of funds for supporting and developing sports infrastructure, ensuring the training of athletes, conducting competitions is a serious problem in front of the 
organizations of the sports industry of noncommercial type (Andreff, Szymanski, 2006). In modern society has changed the social role of sports and physical activity began to be perceived as one of the most important tools in popularizing a healthy lifestyle.

According to the definition of the World Health Organization (WHO), health is a state of full physical, spiritual and social well-being, and not only the lack of illness and physical defects. To support the health of children and young people at the age of 5-17 years, it is necessary to practice at least 60 minutes with physical activity from moderate to high intensity. Adult people at the age of 18-64 should pay for at least 150 minutes a week for sporting and recreational classes of medium intensity or not less than 75 minutes - high intensity (Data and Statistics, 2018, Database, 2020, Global Health Observatory Data Repository, 2018).

A healthy lifestyle is the optimal quality of life, which is determined by motivated human behavior aimed at preserving and strengthening health, in the conditions of environmental and social factors. The main components of a healthy lifestyle are active vital positions; satisfaction of work, physical and spiritual comfort, full rest; balanced rational nutrition; Regular physical and motor activity; psychophysiological pleasure in the family; Economic and material independence, personal hygiene - rational daily mode, body care, hygiene of clothing and footwear; Taking the body (Data and Statistics, 2018, Global Health Observatory Data Repository, 2018).

The idea of "sports for all" for the first time proposed by Pierre de Coberten, the founder of the Modern Olympic Movement in 1919, under the name of this concept, it takes into account the need to transform the sport in the way of active time not only for the privileged youth, but also for all social groups. Since the Second World War, and to a greater extent from the 1960 's of the last century, this idea began to turn into a specific movement that originally appeared in North and Western Europe, and by the end of the 80's. Expanded more than for 80 countries (Health and Participction, 2018, Europe 2020 Strategy, 2018).

The first campaign based on the idea of the movement "Sport for all" was launched in Norway in 1968 (Physical Readiness Campaign). The innovation of this campaign was that it was based on two years of experience in the study of specific examples received throughout Europe, included a project planning, market research, as well as professional advertising. The movement "Sports for Life" appeared in many countries of the world, there are still significant differences in the field of sports in different countries, which, in addition to cultural factors, are really dependent on the economic situation of the country. Wealthy countries have a greater potential for the development of sports infrastructure, in addition, they can count on the assistance of the private sector of the economy. Accordingly, countries with a tense budget have limited opportunities to launch and support sports programs for life, as demand for them may be low due to more important goods and services.

The movement of "sports during life" is characterized by two major trends, one of them - the revival of traditional sports and games, mainly due to the influence of various organizations. The second - globalization of sport caused the world-wide distribution of the most popular sports (Health and Participction, 2018). 
In the formation of a healthy method and improving the quality of life, people have a significant impact on the marketing provision of this process. The quality of life is the perception of the individuals of their position in life in the context of culture and the system of values in which they live, in accordance with goals, expectations, hopes, etc. The quality of life is determined by physical, social, emotional factors of life and are important for humans. This is the degree of comfort of man both inside itself and within the framework of its society (Global Health Observatory Data Repository, 2018, Health and Participetion, 2018).

At this time, the following criteria for assessing the quality of life, due to health are developed: physical (strength, energy, fatigue, pain, discomfort, sleep, rest); psychological (emotions, level of cognitive functions, self-esteem); level of independence (day-to-day activity); social life (personal relationships, social value); Environment (Security, Ecology, Provision, Accessibility and Quality of Medical Aid, Information, Ability to Train, Life) (Data and Statistics, 2018, Health and Participation, 2018).

Sports and recreation activities are related to the improvement of human physical qualities and the formation of a healthy lifestyle. In the process of mastering this activity, a person is formed as a holistic personality. In accordance with the structure of motor activity, the program for the formation of a healthy lifestyle by means of physical culture in the process of marketing activity is structured in three main sections:

1. Study of population demand for a sports product and the formation of proposals, marketing analysis of the information component of sports and recreational activity (the need for knowledge about a healthy lifestyle);

2. Study of the motivational and procedural component of sports and recreational activity (need for physical improvement as a manifestation of a healthy lifestyle);

3. Study of the operating component (demanding of ways of activity on the formation of a healthy lifestyle).

By studying the information component, a marketing study was carried out. The following blocks of the problem were studied: awareness of a healthy lifestyle, including a healthy lifestyle and physical activity in human life; life position; the use of malicious substances; Frequency of sports and recreation activities, etc. The selection of respondents for a sample population was carried out proportional to this general population. From the respondents women were 56\%, men $-44 \%$. Data interviewed by age: $14-$ 18 years $-12.3 \%$; $19-25$ years $-68.7 \%$; $26-$ 35 years $-11 \%$; $36-55$ years $-12.7 \%$.

In the process of research it was found that the importance of physical activity has in human life. According to the results, it was found that: a vital position of $64 \%$ of respondents - active, in 36\% - calm. Regarding bad habits: $72 \%$ - not smoking, $16 \%$ - can smoke a pair of cigarettes per day, $8 \%$ - can smoke half a day and more per day, $4 \%$ can smoke multiple cigarettes for the company; $36 \%$ - they do not drink, $64 \%$ - sometimes drink alcohol in holidays and companies. Only $56 \%$ of respondents support a healthy lifestyle and physical activity, 64\% - take part in sports and recreation programs.

At this time, the sport is considered by a majority of people as additional financial expenses, since there is no support from the state. Most sports clubs without receiving support from the government of their country, turn to 
sponsors, do not receive it there. Investors do not see prospects for financing sports activities, because there are no guarantees on both the state and the side of sports institutions.

Starting from childhood, the child is not interested in sports activities either from the family or from society. Increasingly, well-known athletes advertise alcoholic beverages and tobacco products, increasingly growing demand for "fast-food". Mass media form a passive stereotype of human behavior in relation to a healthy lifestyle and physical activity.

The purpose of marketing programs for the formation of a healthy lifestyle is the study of existing motifs and needs in relation to health, physical and mental qualities, as well as interests aimed at using physical culture in organizing a healthy lifestyle. Accordingly, the following directions are allocated:

- marketing study of demand for the development of basic physical qualities and abilities, strengthening health, expansion of functional capabilities of the body;

- marketing study of demand for the formation of culture of movements, acquisition of skills in physical culture and sports and recreational activities;

- marketing study of the need for knowledge of a healthy lifestyle, physical culture and sports, their history, modern development and role in the formation of a healthy lifestyle, implemented on the basis of marketing strategies.

\section{Conclusions.}

Thus, the conditions for effective marketing support for the formation of a healthy lifestyle and physical activity are the interaction of public administration and organizations of the sports industry in: purposeful personnel training (coaching and pedagogical composition); monitoring of the level of fitness and recreational culture, quality of sports products (sports and recreation programs); Formation of demand and supply to the sports product of the organizations of the sports industry

\section{References}

Andreff W, Stefan Szymanski (2006), Handbook on the economics of sport, MPG Books Ltd, Bodmin, Cjrnwall, UK

Data and statistics (2018), "Database Centers for Disease Control and Prevention", URL: https://www.cdc.gov/nccdphp/dnpao/division-information/datastats/index.htm (Accessed 11 Dec 2018).

Database (2020), "Database European Comission", URL: http://ec.europa.eu/eurostat/data/database (Accessed $11 \mathrm{Dec} 2020$ ).

Global Health Observatory data repository (2018), "Database World Health Organization", URL: http://apps.who.int/gho/data/node.main.A893?lang=en (Accessed 11 Dec 2018)

Health and Participftion (2018), "Database European Comission". URL: https://ec.europa.eu/sport/policy/societal-role/health-participation_en (Accessed 11 Dec 2018)

Europe 2020 strategy (2018), "Database European Comission", URL: https://ec.europa.eu/info/business-economy-euro/economic-and-fiscal-policycoordination/eu-economic-governance-monitoring-preventioncorrection/european-semester/framework/europe-2020strategy_en\#thestrategysetouttargetsinthe5followingfields (Accessed 11 Dec 2018). 